Коломосць Юлія Олександрівна доцент кафедри менеджменту і права Дніпровського державного аграрно-економічного університету, кандидат юридичних наук, вул. Сергія Єфремова, 25, Дніпро, 49000, тел.: (056) 744-81-32, e-mail: info@dsau.dp.ua, https://orcid.org/0000-0002-5379-5228

\title{
ЕВОЛЮЦЯ СТАНОВЛЕННЯ НОРМАТИВНО-ПРАВОВОГО РЕГУЛЮВАННЯ КОНСТИТУЦЙНОГО ПРАВА НА СТРАЙК ЯК ОСНОВИ РОЗВИТКУ ПУБЛІЧНОГО УПРАВЛІННЯ
}

Анотація. У статті проаналізований історичний розвиток нормативноправових механізмів регулювання конституційного права на страйк як основи розвитку публічного управління

Обгрунтовано, що у системі публічного управління неоднозначність конституційно-правового регулювання права на страйк - пряме та опосередковане - обумовлене об'єктивними чинниками, має свої особливості, які надають нам можливість виокремити такі групи зарубіжних країн: у ряді європейських держав воно прямо передбачено конституціями та, як правило, деталізовано у законах, що прийняті у розвиток положень основного закону суспільства i держави. Значущість прав другого покоління, включно і права на страйк, була визнана хронологічно у другу чергу, а саме після визнання прав першого покоління - на життя, гідність, особисту недоторканність тощо. Виходячи 3 цього, інкорпорація даного права у національне законодавство головним чином відбулася у тих державах, де зміна політичного режиму супроводжувалася прийняттям нових конституцій, що відображали міжнародні правові стандарти (приклад - країни колишнього соціалістичного табору, серед яких і Україна, а також Іспанія, Португалія, Туреччина тощо); право на страйк передбачено конституціями, але прямо не проголошується. Такий підхід характерний для тих країн, де зміни у законодавстві за своєю прогресивністю багато в чому випереджали свою епоху (Конституції Франції 1946 та 1958 рр., Італії 1947 р.), в силу чого законодавець намагався обмежити бурхливий розвиток суспільних відносин, або ж для тих держав, де через слабкість демократичних традицій існувала небезпека зловживань цим правом (Албанія, Польща, Угорщина) та інші; зарубіжні країни, в яких право на страйк прямо не закріплене, однак виводиться із конституційних положень про право на об'єднання (асоціацію) - ФРН, Японія, Фінляндія, Швеція; 
не регламентовано навіть законодавчо, а суттєву роль при визначенні досліджуваного права відіграють: а) судова практика (Бельгія, Велика Британія, Данія, Люксембург) й здебільшого базується на принципі "дозволено те, що не заборонено"; б) національно-культурні традиції (Узбекистан, Туркменістан).

Ключові слова: публічне управління, конституційні права, право на страйк, розвиток системи трудових відносин, нормативно-правові механізми публічного управління.

Kolomoyets Yuliya Oleksandrivna Associate Professo of Management and Law, Dnipro State Agrarian and Economic University, Candidate of Law, Serhiy Yefremov St., 25, Dnipro, 49000, tel .: (056) 744-81-32, e-mail: info@dsau.dp.ua, https://orcid.org/0000-0002-5379-5228.

\section{THE EVOLUTION OF THE FORMATION OF LEGAL REGULATION OF THE CONSTITUTIONAL RIGHT TO STRIKE AS A BASIS FOR THE DEVELOPMENT OF PUBLIC ADMINISTRATION}

Abstract. The article analyzes the historical development of legal mechanisms for regulating the constitutional right to strike as a basis for the development of public administration.

The author substantiates that in the system of public administration the ambiguity of constitutional and legal regulation of the right to strike - direct and indirect - due to objective factors, has its own features that allow us to distinguish the following groups of foreign countries: in some European countries it is directly provided by constitutions and, as a rule, are detailed in the laws accepted in development of provisions of the basic law of a society and the state. The importance of the rights of the second generation, including the right to strike, was recognized chronologically in the second place, namely after the recognition of the rights of the first generation - to life, dignity, personal integrity and so on. Based on this, the incorporation of this right into national legislation took place mainly in those countries where the change of political regime was accompanied by the adoption of new constitutions that reflected international legal standards (for example - the former socialist camp, including Ukraine and Spain, Portugal, Turkey, etc.); the right to strike is enshrined in the constitutions, but is not explicitly proclaimed. This approach is typical of those countries where changes in legislation in its progressiveness in many ways ahead of its time (the Constitution of France in 1946 and 1958, Italy in 1947), due to which the legislator tried to limit the rapid development of social relations, states where due to the weakness of democratic traditions there was a danger of abuse of this right (Albania, Poland, Hungary) and others; foreign countries, in which the right to strike is not directly enshrined, but is 
derived from the constitutional provisions on the right to unite (association) - Germany, Japan, Finland, Sweden; not even regulated by law, but a significant role in determining the law under study is played by: a) case law (Belgium, Great Britain, Denmark, Luxembourg) and is mostly based on the principle of "allowed what is not forbidden"; b) national and cultural traditions (Uzbekistan, Turkmenistan).

Keywords: public administration, constitutional rights, right to strike, development of the system of labor relations, normative-legal mechanisms of public administration.

Постановка проблеми. Невід’ємною ознакою демократичної держави та громадянського суспільства є нормативно-правова регламентація права людини на страйк. Активне використання страйкових методів боротьби зумовлює потребу в детальному вивченні цього права, його правового режиму i суспільного значення. Для цього необхідно: а) дослідити еволюцію нормативно-правового регулювання права на страйк; б) охарактеризувати міжнародний і національний рівні його регулювання; в) надати визначення поняття "нормативно-правове регулювання права на страйк".

Досліджуючи конституційне право на страйк у сучасних економічних i правових умовах, можна вести мову про наявні дві основні сфери застосування особистої праці людини: перша включає право кожного на підприємницьку діяльність, яка не заборонена законом (ч. 1 ст. 42 Конституції України), а друга передбачає можливість кожного заробляти собі на життя працею, яку він вільно обирає або на яку вільно погоджується (ч. 1 ст. 43 Конституції України).

Аналіз останніх досліджень i публікацій. Питання регулювання конституційного права на страйк як основи розвитку публічного управління досліджувалося багатьма як вітчизняними, так і зарубіжними вченими, у тому числі: А. Колодій, А. Олійник, В. Погорілко, Ж. Пустовіт, П. Рабінович, В. Серьогін, О. Скакун, Ю. Тодика, М. Хавронюка В. Федоренко та інших науковців. Безпосередню увагу досліджуваній можливості приділяли В. Кондратьєв, І. Куян, М. Процишен, Н. Швець, Н. Погрібна. Однак певна фрагментарність наявних розвідок щодо регулювання конституційного права на страйк як основи розвитку публічного управління, а саме відсутність системних досліджень проблеми регулювання конституційного права на страйк як основи розвитку публічного управління.

Мета статті - проведення системного аналізу регулювання конституційного права на страйк як основи розвитку публічного управління в Україні та за кордоном.

Виклад матеріалу. Начала нормативно-правового регулювання права на страйк, перші згадки про нього мають глибокі коріння. Звернення до них на 
сучасному етапі державотворення безпосередньо пов'язане із потребою втілення у практику цінностей конституціоналізму. Удосконалення правового регулювання суспільних відносин у даній сфері потребують урахування у державотворчому процесі як національного, так і зарубіжного досвіду. Саме в такому аспекті проблематика нормативного становлення права на страйк потребує грунтовного розгляду у вітчизняній юридичній науці, що надасть можливість отримати цілісне бачення щодо його виникнення, законодавчого закріплення та перспектив подальшого розвитку.

Нормативному закріпленню права на страйк передували самі страйки як соціальне явище, що були відомі давно, але вони не були легітимними і навіть можливість їх заперечувалась. Лише з часом страйки стали помітним явищем у соціальному житті та поступово перетворились на такий суттєвий фактор, що був включений до сфери державно-правової регламентації [1, с. 54].

Уже в першій четверті XIX ст. в англійському суспільстві поступово змінюється ставлення до професійних спілок та організацій. Так, у 1824 р. під впливом масових виступів робітників було скасовано заборону на створення професійних спілок $з$ метою досягнення економічних цілей, зокрема щодо укладання угоди стосовно умов трудового найму, підвищення заробітної плати, скорочення робочого дня тощо. Для досягнення поставлених цілей профспілки, як правило, вдавалися до страйків [2, с. 81].

1825 рік у цій країні був ознаменований прийняттям нового закону, що дозволяв об'єднання робітників. Саме з цього часу отримав розвиток рух тредюніонів (тред-юніони - профспілки в Англії і країнах, що входили до складу Британської імперії, зазвичай вони об'єднували робітників за професією). У 30 40-х pp. XIX ст. в Англії значного поширення набув рух робітників за свої права (чартистський рух). Однак це, у свою чергу, потягло за собою прийняття ряду законів, котрі обмежували свободу об'єднань. Також була збережена можливість кримінального переслідування за будь-які дії, які могли б нанести збитки промисловості або обмежити власників підприємств - промисловців, в тому числі й за страйки.

У Франції законом 1849 р. було збережено заборону на об’єднання (спілки), однак урівняно у цій забороні як працівників, так і роботодавців. Починаючи 3 1832 р. у державах Німецького союзу вже дозволялося створення робітничих асоціацій, але тільки із санкції уряду.

У Росії, до складу якої входила значна кількість українських земель, як і в більшості європейських держав того часу була встановлена заборона на страйки під загрозою кримінального покарання (Уложення про покарання кримінальні та виправні від 1845 р.) [3, с. 174 - 276].

Однак уже друга половина XIX ст. у Свропі була ознаменована суттєвими 
зрушеннями у сфері правової регламентації організації та проведення страйків: координацію страйкової боротьби взяли на себе перші робітничі союзи профспілки. Наслідком цього стало те, що у 1871 р. в Англії законом про профспілки було: а) запроваджено їх добровільну державну реєстрацію; б) заборонено їх судове переслідування. Також законом 1875 р. про угоди й охорону власності було скасовано притягнення членів профспілок до кримінальної відповідальності за участь у страйках. Тобто, починаючи з другої половини XIX ст. однією з основ британського права стала формула, за якою профспілкові активісти могли вільно організовувати акції протесту в промисловості, не побоюючись судових переслідувань. Таке право поширювалося на тих, хто здійснював чи закликав інших розпочати страйкові дії у промисловій сфері. Відповідно до законів Англії 1875 і 1906 рр. ці дії самі по собі вже не вважалися злочинними, a їх організатори не підлягали кримінальному покаранню. Англійський юрист К. Веддерберн назвав це право "золотою формулою" і визначив за нею центральне місце в британському законодавстві про страйки [4, с. 222].

На початку ХХ ст. в Англії відбувається ряд законодавчих змін: ліквідуються обмеження щодо діяльності профспілок, визнається законність страйків, скасовується кримінально-правова відповідальність за шкоду, що була нанесена страйком тощо. Водночас, відмовившись від кримінального переслідування, буржуазія стала в таких випадках притягати керівників профспілок до матеріальної відповідальності; страйки стали кваліфікуватися англійськими судами як цивільні правопорушення, спрямовані на нанесення матеріальної шкоди підприємцю [5, с. 131].

Аналогічно у Франції законом від 21 березня 1884 р. було скасовано кримінальне переслідування за об'єднання, проголошено свободу його створення і право на колективні дії. Врешті-решт даний принцип закріпився законом від 1 липня 1901 р., що скасовував ст. ст. 291 - 294 Кримінального кодексу, які містили положення про заборону свободи зібрань, передбачали кримінальне переслідування за коаліцію [6].

У Німеччині право спілок і зборів було проголошено імперською конституцією 19 квітня 1908 р.. Хоча цей Закон і містив різні обмеження щодо права на об'єднання, однак все ж таки він був кроком уперед у здійсненні принципів політичної свободи і став знаковим завоюванням демократичного та страйкового руху у цій державі. Відповідно до положень вищезазначеного закону, для створення спілок робітників, які переслідують економічні цілі, не вимагалось попереднього дозволу [7, с. 50 - 51].

У США на початку 1880-х рр. було утворено Американську федерацію праці, однак правової бази для здійснення законних колективних дій у цій державі не було. Тільки у 1914 р. у США приймається Закон Клейтона. Його основні 
положення зводилися до того, що профспілки вперше розглядалися як законні об’єднання та визнавалися такими, що не порушують свободу торгівлі. Однак при розгляді колективних дій профспілок важлива роль відводилася суддям, які практично одноосібно приймали рішення, не визнаючи, як правило, дію антитрестовського законодавства; на винних та за неповагу до суду накладалися покарання у вигляді штрафу або тюремного ув’язнення. Виняток складали тільки ті дії профспілок, які мали правомірний характер [8, с. 12].

Отже, у США закон Клейтона хоча й встановлював деякі обмеження для видання судових приписів, однак профспілки не були захищені як щодо організації страйків, так і в інших питаннях своєї діяльності.

У Російській імперії, до складу якої входило більшість українських земель, розвиток масового страйкового руху розпочався лише після скасування у 1861 р. кріпосного права - у 70-х - 80-х pp. XIX ст. - 3 початком розвитку промисловості й формування робітничого класу. 3 фактичною появою страйків був пов'язаний $\mathrm{i}$ розвиток законодавства про них. Так, в урядовому циркулярі № 295 (грудень 1871 р.) зазначалося, що під словом "страйк" слід розуміти припинення працівниками роботи з метою домогтися підвищення заробітної плати, а також будь-яку угоду промисловців проти споживачів у формі припинення виробництва чи підвищення цін на продукти, переважно першої необхідності [9, с. 352].

80-і роки XIX століття в Росії були ознаменовані тим, що сформувалось i увійшло у практику поняття колективного трудового конфлікту під назвою "забастовка", "стачка" (страйк), про які йшлося в законі "Про нагляд за закладами фабричної промисловості і про взаємні відносини фабрикантів і робітників" від 03.07.1886 р.. Російське законодавство того періоду не визначало чіткого порядку вирішення колективного трудового спору. При цьому діяльність такого наглядового органу як фабрична інспекція не мала за мету врегулювання конфліктів, так як наявних норм було недостатньо для примирення [83, с. 113]. Вищезазначений закон складався 3 двох частин, що включав єдині загальнодержавні правила найму, а також особливі настанови про нагляд за закладами фабричної промисловості та взаємовідносини між фабрикантами та робітниками. Ці правила розвивали загальні правила, а також частково містили нові положення, наприклад, щодо створення органів нагляду - так званих губернських та столичних присутствій у справах фабричного законодавства.

Також вищезазначений закон уперше відокремлював припинення від розірвання договору найму. Підставою для останнього могли бути як ініціатива власника (завідуючого) підприємства, так і ініціатива робітника.

За ст. 19 цього закону договір найму припинявся: 1) за згодою сторін; 2) у разі закінчення строку найму; 3) у разі виконання роботи, що була обумовлена строком найму; 4) у випадку закінчення двох тижнів з дня подання заяви однієї із 
сторін про намір розірвати договір (якщо він був укладений на невизначений строк); 5) вислання робітника 3 місця виконання договору (за розпорядженням компетентного державного органу влади) чи засудження його до ув'язнення на відповідний строк, що унеможливлює виконання договору; 6) у разі вступу робітника на обов'язкову військову чи громадську службу; 7) при відмові установи відновити робітникові строкову посвідку на проживання; 8) у разі зупинення роботи на підприємстві внаслідок пожежі, стихійного лиха тощо на строк понад 7 днів.

Цим же законодавчим актом було визначено й декілька підстав для розірвання договору найму 3 ініціативи власника (завідуючого) фабрики чи заводу. Однак звільнений мав право оскаржити це в суд. При цьому визнання скарги як такої, що мала підстави, мало наслідком прийняття судом рішення про відшкодовування робітникам понесених збитків. Страйк, примушення до нього чи самовільна відмова працівників від роботи були заборонені під страхом позбавлення волі [10, с. 40 - 41].

У Росії, починаючи 31886 р., покарання, які накладалися мировими суддями, передбачали, що особи, винні у самовільній відмові від роботи до закінчення терміну найму або без попередження господаря (при безстроковому договорі) підлягають арешту на строк до 1 місяця. До Уложення про покарання кримінальні i виправні (1845 р.), з метою боротьби зі страйками, також було включено спеціальну статтю про кримінальну відповідальність "за безпорядки скопом" [3, с. 174 - 276].

Однак події у Російській імперії початку ХХ століття (революція 1905 - 1907 рр.) підштовхнули уряд до суттєвих змін у нормативно-правовому регулюванні взаємин між найманими працівниками та роботодавцями. Так, відповідно до Тимчасових правил від 2 грудня 1905 р. "О наказуемости наиболее опасных проявлений в забастовках", у Росії були фактично легалізовані економічні страйки. В Уложенні про покарання кримінальні і виправні (1845р.) були збережені тільки статті, що передбачали відповідальність не за страйки як такі, а за насильницькі дії 3 боку страйкарів, пошкодження майна підприємств i посягання на свободу праці. Водночас Тимчасові правила визнавали незаконними та встановлювали кримінальну відповідальність за страйк у сфері життєво важливих послуг на підприємствах, припинення діяльності яких загрожувало б безпеці держави або створювало загрозу суспільної бездіяльності. Державним службовцям заборонялося брати участь у страйках під загрозою позбавлення права зайняття відповідної посади тощо [11].

4 березня 1906 р. були видані "Тимчасові правила про товариства і спілки", які об'єднували різні правові норми, що встановлювали порядок створення та діяльності громадських об'єднань: заборонялися публікації, діяльність спілок, 
товариств, які загрожували громадському спокою й безпеці держави, а винних в організації страйків передбачалось притягати до кримінальної відповідальності $[12$, с. 556].

Отже, аналіз нормативно-правих актів кінця XIX - початку XX ст. ряду європейських країн та США свідчить про те, що в умовах капіталістичного способу виробництва, концентрації найманих працівників на великих підприємствах у цих державах намітився поступовий перехід від категоричної заборони страйку (звідси, й відповідного права) та кваліфікації його як злочинного діяння, до його легалізації. Водночас у Росії, до складу якої входило більшість українських земель, форми колективного захисту трудових прав ще не одержали належного розвитку, а страйки здебільшого розглядалися як протиправні й кримінально карані діяння.

Щодо західноукраїнського суспільства, то наприкінці XIX - на початку XX ст. 3 розвитком соціальних відносин на його територіях також відбувалася подальша соціальна поляризація. Зокрема, у 70-х рр. ХІХ ст. страйковий рух набув значного поширення у Східній Галичині. Страйки друкарів Львова у 1870 71 pр. та 300 робітників швейних майстерень, а також стельмахів, колісників Львова, нафтовиків Борислава та працівників інших професій мали успіх, в результаті чого страйкуючим було підвищено заробітну плату. Під керівництвом профспілок до страйкового руху поступово долучалися робітники Північної Буковини й Закарпаття (1897 - 1899 рр. - виступи чернівецьких будівельників, меблярів Ужгорода). Подібне відбувалося і в інших містах цих регіонів.

Соціальні конфлікти тривали й на селі. Регіональною особливістю селянського руху на західноукраїнських землях наприкінці XIX ст. стала поява нової форми протесту - віча (мітинги). Активним учасником цих заходів був український письменник Іван Франко, що надавав їм усебічну підтримку [13].

Однак нормативно-правове регулювання порядку проведення страйків, закріплення відповідного права на західноукраїнських землях наприкінці XIX - на початку XX ст. було відсутнє. Законодавство про працю відставало від вимог часу, а механізми впливу на його порушників були малоефективними. Відтак, інтереси найманих працівників опинилися на периферії державної економічної політики. У цей час робітничі верстви в Україні почали формулювати свої соціально-економічні потреби та вимагали їх задоволення. Функцію захисту соціально-економічних інтересів найманого працівника поступово почали брати на себе професійні спілки.

У Росії, після подій Лютневої буржуазної революції 1917 р., Тимчасовим урядом було підготовлено досить радикальний законопроект про страйки. Ним було легалізовано політичні страйки, скасовано майнову відповідальність їх організаторів і учасників. Арештом на значний термін каралися особи, що 
надавали іншому підприємцю інформацію про участь робітника у страйку; було встановлено відповідальність за перешкоджання страйкам. Слід погодитись із тим, що вищезазначений проект надавав російським робітникам право на страйк у значно більшому обсязі, ніж це було регламентовано законодавством інших європейських країн того періоду [14, с. 79].

У цілому діяльність Тимчасового уряду в Росії була пов'язана 3 трьома нормативними актами щодо регламентування права на страйк, які стосувалися: а) організації примирних камер і третейських судів; б) примирних установ для розгляду конфліктів між робітниками та підприємцями на підприємствах, в установах і організаціях, які контролювалися урядом; в) законопроекту про промислові суди [15, с. 24].

На теренах України становлення у 1917 році власної державності було зумовлене попередніми етапами національного відродження та політичними процесами, що відбувалися в Російській імперії. У березні 1917 р. діяльність створеної Центральної Ради була зосереджена головним чином на вирішенні національного питання, досягненні автономії України тощо. Партії, які входили до Ради, ухилялися від обговорення та вирішення гострих соціально-економічних питань, включно й щодо права на страйк, і підхід до їх вирішення у них значно різнився.

Жовтнева революція 1917 року у Росії та запровадження соціалістичних ідей сприяли тому, що український народ розпочав будівництво власної держави. Наприклад, програма соціально-економічних перетворень Центральної Ради була викладена в її універсалах, зокрема в Третьому та Четвертому. Так, оголосивши 7 листопада 1917 р. днем утворення Української Народної Республіки (УНР), Центральна Рада у Третьому універсалі обнародувала основні принципи своєї політики. 3 огляду на тему нашого дослідження, важливим було те, що цей Універсал декларував необхідність "доброго упорядкування виробництва, рівномірного розподілення продуктів споживання й кращої організації праці". 3 цією метою Генеральному секретарству праці було доручено спільно 3 представниками робітників "установити державний контроль над продукцією на Україні". Проголошувалося запровадження 8-годинного робочого дня; акцентувалася увага на тому, що у новоствореній державі мають бути забезпечені всі свободи, здобуті всеросійською революцією, а саме: свобода слова, друку, віри, зібрань, союзів, недоторканості особи й мешкання, а також страйків [16].

Однак у реалізації окреслених Третім універсалом програмних заходів уряд УНР не виявив ані послідовності, ані рішучості: не був встановлений державний контроль над промисловістю - робітники не зрозуміли його суті, а підприємці сприйняли вороже; на промислових підприємствах України зростало безробіття.

29 квітня 1918 р. Центральною Радою було обговорено i прийнято 
Конституцію УНР. Статтею 17 цього документа було закріплено, що "громадянин УНР і ніхто інший на території іï не може бути обмежений в правах слова, друку, сумління, організації, страйку, скільки він не переступає при тім постанов карного права" [17]. Однак ці демократичні положення залишилися нереалізованими. Того ж дня 29 квітня 1918 р. було здійснено державний переворот, влада Центральної Ради була скасована, а гетьманом України було проголошено Павла Скоропадського.

Нові порядки, закріплені урядом й адміністрацією П. Скоропадського, зокрема, запровадження 12-годинного робочого дня, каральні експедиції, організовані за допомогою німецького війська, викликали опір селянських i робітничих мас, наслідком чого стали численні страйки. Правовим засобом боротьби проти страйків та саботажів, які охоплювали все більше різних підприємств, стало прийняття 19 липня 1918 р. "Постанови про відновлення на Україні сили закону Російської держави від 2 грудня 1905 року про покарання за участь у деяких страйках", яка передбачала переслідування в кримінальному порядку й сувору відповідальність за будь-які заклики чи агітацію до страйків [18, с. 32].

Після встановлення в Україні радянської влади (березень 1919 р.) у державі не було ухвалено жодного нормативного акту щодо вирішення трудових спорів (конфліктів). У кодексах законів про працю РРФСР 1918 та 1922 рр. також були відсутні будь-які норми, які б регулювали вирішення трудових спорів (конфліктів) та проведення страйків включно.

Із переходом радянського суспільства до державно-авторитарних економічних відносин було послаблено захист трудових гарантій та інтересів робітників у сфері найманої праці. Роль колективних договорів як джерела права поступово звужувалась, а з 1933 року їх узагалі припинили укладати [19, с. 454].

Мирні робітничі демонстрації щодо покращання умов праці позначилися введенням до радянського законодавства більш жорсткої нормативно-правової бази, яка посилювала терор щодо страйкарів. Так, 23 січня 1935 р. прокурором СРСР була видана директива, за якою антирадянські виступи, що підтримували акції проти керівництва держави, кваліфікувалися виключно як контрреволюційна пропаганда та агітація [20, с. 38 - 39]. Це мало наслідком численні арешти страйкуючих.

Значна кількість фактів другої половини 1930-х рр. свідчить про те, що радянська система жорстко придушувала будь-які прояви робітничого о опору [21]. В таких умовах кривавого терору, із подальшим розгортанням політики масових репресій в СРСР взагалі та Українській РСР зокрема, страйковий рух повністю зникає як форма соціального спротиву тоталітарному режимові.

Поряд із кодексами законів про працю РРФСР 1918 та 1922 рр., у 
післявоєнний період Кодекс законів про працю Української РСР 1971 р. також не містив жодного положення щодо правової регламентації права на страйк. Нічого не було зазначено про досліджуване право і в "Основах законодавства Союзу РСР і союзних республік про працю" 1970 року [22].

Водночас слід звернути увагу і на той суттєвий факт, що і суто прямої заборони на страйк у радянському трудовому законодавстві ніколи не існувало. Навпаки, постанова ЦВК і РНК СРСР від 13 січня 1929 р. у непрямій формі забороняла вимагати відшкодування зі страйкових фондів профспілкових органів [23, с. 7]. Тобто, можна вважати, що у такому вигляді право на страйк було легалізовано. Потому назва Постанови офіційно не змінювалась. Таким чином, їі положення зберігали свою чинність до прийняття Закону СРСР "Про порядок вирішення колективних трудових спорів (конфліктів)" (1989 р.).

У вищезазначеному законі містився перелік питань, 3 приводу яких міг відбутися страйк, визначався порядок висунення вимог, можливість розгляду суперечок комісією з примирення або трудовим арбітражем. В ньому були також викладені підстави визнання страйків незаконними та виписано процедуру такого визнання [24]. Однак цей нормативно-правовий акт виявився недосконалим, тобто не врегульовував усі питання, що виникали при вирішенні колективних спорів. Його ефективність була невисокою, оскільки він закріпив складний та громіздкий для правозастосування механізм. У зв’язку з цим 20 травня 1991 р. було прийнято нову редакцію цього Закону [25]. Але знову ж таки, процедурі оголошення i проведення страйку, відповідно до даного Закону, були характерні надмірні формальності; ефективність даного акту була також невисокою.

Отже, в радянський період, після згортання нової економічної політики (НЕПу), фактично право на страйк було заборонено - всі економічні страйки розглядалися як наслідок політичного заколоту i жорстоко придушувалися. Радянське законодавство як довоєнного (20 - 30-і рр. ХХ ст.), так і післявоєнного (друга половина 40 - 70-х рр.) періодів не містило жодної норми щодо права на страйк чи процедури його оголошення та проведення. У тоталітарній державі інтереси виробництва виходили на перший план. Кодекс законів про працю УРСР 1971 р. передбачав лише процедуру вирішення індивідуальних трудових спорів у комісіях з трудових спорів та в районних (міських) народних судах [26, с. 375]. Поняття колективного трудового спору (конфлікту), процедури його вирішення, а також страйку були відсутні. Вважалося, що в соціалістичному суспільстві немає місця ніяким підставам для такого явища та, відповідно, і для закріплення права на страйк.

У радянський період право на страйк практично не мало свого закріплення ні на конституційному, ні на законодавчому рівнях. Деякі зрушення у цій сфері відбулися лише наприкінці 1980-х рр. під впливом відродження робітничого 
страйкового руху, що був обумовлений кризою в економіці, політиці, трудових відносинах. Верховною Радою СРСР було прийнято Закон "Про порядок розгляду колективних трудових спорів (конфліктів)". Однак цей документ, як у першій редакції від 9 жовтня 1989 р., так і в другій від 20 травня 1991 р., виявився не здатним врегулювати соціально-трудові відносини в нових економічних умовах.

Висновки. У системі публічного управління неоднозначність конституційноправового регулювання права на страйк - пряме та опосередковане - обумовлене об'єктивними чинниками, має свої особливості, які надають нам можливість виокремити такі групи зарубіжних країн:

1) у ряді європейських держав воно прямо передбачено конституціями та, як правило, деталізовано у законах, що прийняті у розвиток положень основного закону суспільства i держави. Значущість прав другого покоління, включно i права на страйк, була визнана хронологічно у другу чергу, а саме після визнання прав першого покоління - на життя, гідність, особисту недоторканність тощо. Виходячи 3 цього, інкорпорація даного права у національне законодавство головним чином відбулася у тих державах, де зміна політичного режиму супроводжувалася прийняттям нових конституцій, що відображали міжнародні правові стандарти (приклад - країни колишнього соціалістичного табору, серед яких і Україна, а також Іспанія, Португалія, Туреччина тощо);

2) право на страйк передбачено конституціями, але прямо не проголошується. Такий підхід характерний для тих країн, де зміни у законодавстві за своєю прогресивністю багато в чому випереджали свою епоху (Конституції Франції 1946 та 1958 рр., Італії 1947 р.), в силу чого законодавець намагався обмежити бурхливий розвиток суспільних відносин, або ж для тих держав, де через слабкість демократичних традицій існувала небезпека зловживань цим правом (Албанія, Польща, Угорщина) та інші;

3) зарубіжні країни, в яких право на страйк прямо не закріплене, однак виводиться із конституційних положень про право на об'єднання (асоціацію) ФРН, Японія, Фінляндія, Швеція;

4) не регламентовано навіть законодавчо, а суттєву роль при визначенні досліджуваного права відіграють: а) судова практика (Бельгія, Велика Британія, Данія, Люксембург) й здебільшого базується на принципі "дозволено те, що не заборонено"; б) національно-культурні традиції (Узбекистан, Туркменістан).

\section{Лimepamypa:}

1. Миронов В. К. Право на забастовку как новый институт трудового права стран Восточной Европы. Вестник Моск. ун-та. 1998. Сер. 11. Право. № 2. С. 53 - 62.

2. Севрюков Д.Г. Публічно-правові і приватноправові методи регулювання трудових відносин у країнах Західної Європи і США з кінця XVIII - до початку XXI століть: Дис...канд. юрид. наук: 12.00.01. Х., 2008. 191 с. 
3. Российское законодательство X - XX веков: в 9 томах. Законодательство первой половины XIX века / Ответственный ред. тома: О.И. Чистяков. Том 6. Издательство Юридическая литература, 1988. 431 с.

4. Wedderbern K. W. The worker and the law. Harmondsworth, 1968. 358 p.

5. Каленский, В. Г. Об ограничении права на забастовку в Англии. Правоведение. 1964. № 4. С. $131-135$.

6. Французский закон 1 июля 1901 года об ассоциациях и религиозных конгрегациях и относящиеся к нему декреты 16 августа 1901 года. URL: http://www.law.edu.ru/article/article.asp?articleID=1408803.

7. Хрестоматия по новой истории: Второй период: Пособие для учителя / Сост. П.И. Остриков; Т.В. Алентьева; П.П. Вандель; И.Г. Жиряков; Г.И. Зверева. М.: Просвещение, 1993. $320 \mathrm{c}$.

8. Баглай, М. В. Законодательство США в борьбе с забастовочным движением. М. : Госюриздат, 1960. 192 с.

9. Российское законодательство Х-ХХ веков. В 9 т. Т. 8. Судебная реформа. М.: Юрид. лит., 1991. 496 с.

10. Богдан В. И. Трудовое законодательство России. Историко-правовой аналіз. М. : Ось-89, 2003. 192 с.

11. Трудовые конфликты и рабочее движение в России на рубеже XIX-XX вв. / И. М. Пушкарева [и др.]; отв. ред. И. М. Пушкарева. СПб. : Алетейя, 2011. 476 с.

12. Історія держави і права України: підручник: [у 2 т.] / кол. авторів: В.Д. Гончаренко, А.Й. Рогожин, О.Д. Святоцький та ін. К.: Концерн «Видавничий дім «Ін Юре», 2003. Т. 1. 2003. $656 \mathrm{c}$.

13. Борисенко В.Й. Західноукраїнські землі в другій половині XIX ст. . URL: http:// borysenko.npu.edu.ua/index.php/teksts/33-lekcia-30.

14. Киселев И. Я. Трудовое право России: историко-правовое исследование. М.: НОРМА, $2001.384 \mathrm{c}$.

15. Слюсарь А.Н. Правовые проблемы становления законодательства Украины о порядке разрешения коллективных трудовых споров (конфликтов): Дис...канд. юрид. наук: 12.00.05. Х., 1995. 207 с.

16. Третій Універсал Української Центральної Ради. 7 листопада 1917 р. ЦДАВО України, ф. 1115, оп. 1, спр. 4, арк. URL: http://constituanta.blogspot.com/2011/03/i-1917_07.html

17. Конституція Української Народної Республіки (Статут про державний устрій, права i вільності УHP) Державні утворення (1917-1920). URL: Режим доступу: http://zakon0.rada.gov.ua/laws/show/n0002300-18.

18. Гламазда П. Посилення каральної спрямованості законодавства Української Держави доби Гетьманату Павла Скоропадського(квітень - грудень 1918 р.). Iсторико-правовий часопис. 2013. №2. С. $29-34$

19. Прокопенко В. І. Трудове право України: Підручник. Х.: Фірма «Консум», 1998. 480 с.

20. Реабілітація репресованих: Законодавство і судова практика / [уклад. Маляренко В. Т., Овчинніков Є. І.; під ред. В. Т. Маляренко]. Київ: Юрінком, 1997. 461 с.

21. Крайнік Р. Страйковий рух робітників півдня України в першій половині 1930-х років. URL: http://journal.mandrivets.com/images/file/Kraynik_2010_3.pdf

22. Закон СССР от 15 июля 1970 года № 2-VIII «Об утверждении Основ законодательства Союза ССР и союзных республик о труде». Ведомости Верховного Совета СССР. 1970. № 29. Ст. 265. 
23. Лушникова М.В. Трудовые споры в СССР : учеб. пособие. Ярославль : ЯрГУ, 1991. $84 \mathrm{c}$.

24. О порядке разрешения коллективных трудовых споров (конфликтов): Закон СССР от 09.10.1989 № 580-I. Ведомости Съезда народных депутатов СССР и Верховного Совета СССР. 1989. №18. Ст. 342.

25. О порядке разрешения коллективных трудовых споров (конфликтов): Закон СССР от 23.11.1995№ 175-Ф3. Ведомости Съезда народных депутатов СССР и Верховного Совета СССР. 1991. № 23. Ст. 654.

26. Кодекс законів про працю УРСР: Закон від 10.12.1971 № 322-VIII. Biдомості Верховної Ради. 1971.№ 50. Ст. 375.

\section{References:}

1. Mironov, V. K. (1998). Pravo na zabastovku kak novy’j institut trudovogo prava stran Vostochnoj Evropy` [The right to strike as a new institution of labor law in Eastern Europe]. Vestnik Mosk. un-ta - Bulletin of Moscow. un-ta. (11) (2): 53 - 62. [in Russian].

2. Sevriukov, D.H. (2008). Publichno-pravovi i pryvatnopravovi metody rehuliuvannia trudovykh vidnosyn u krainakh Zakhidnoi Yevropy i SShA z kintsia KhVIII - do pochatku KhKhI stolit [Public and private methods of regulating labor relations in Western Europe and the United States from the late eighteenth to early twentieth centuries]: Dis...kand. yurid. nauk: 12.00.01. Kh. [in Ukrainian].

3. Chistyakov O.I. (1998) Rossijskoe zakonodatel`stvo Kh $-\mathrm{KhKh}$ vekov: v 9 tomakh. Zakonodatel`stvo pervoj poloviny` KhIKh veka [Russian legislation of the X - XX centuries: in 9 volumes. Legislation of the first half of the XIX century]. Tom 6. Izdatel'stvo Yuridicheskaya literatura. [in Russian].

4. Wedderbern, K. W. (1968). The worker and the law. Harmondsworth. [in English].

5. Kalenskij, V. G. (1964) Ob ogranichenii prava na zabastovku v Anglii [On the restriction of the right to strike in England]. Pravovedenie - Jurisprudence, (4). [in Russian].

6. Franczuzskij zakon 1 iyulya 1901 goda ob assocziacziyakh i religiozny`kh kongregacziyakh i otnosyashhiesya k nemu dekrety`16 avgusta 1901 goda [The French Law of 1 July 1901 on Associations and Religious Congregations and the related decrees of 16 August 1901]. Retrieved from: http://www.law.edu.ru/article/article.asp?articleID=1408803. [in Russian].

7. Ostrikov P.I., Alent`eva T.V., Vandel` P.P., Zhiryakov I.G. \& Zvereva G.I. (1993). Khrestomatiya po novoj istorii: Vtoroj period: Posobie dlya uchitelya [A textbook on new history: The second period: A guide for teachers]. M.: Prosveshhenie. [in Russian].

8. Baglaj, M. V. (1960). Zakonodatel`stvo SShA v bor`be s zabastovochny`m dvizheniem [US legislation in the fight against the strike movement]. M. : Gosyurizdat. [in Russian].

9. Rossijskoe zakonodatel'stvo $\mathrm{Kh}-\mathrm{KhKh}$ vekov. V 9 t. T. 8. Sudebnaya reforma [Russian legislation of the X - XX centuries. In 9 vols. Vol. 8. Judicial reform] (1991). M.: Yurid. lit. [in Russian].

10. Bogdan, V. I. (2003). Trudovoe zakonodatel`stvo Rossii. Istoriko-pravovoj anali z [Labor legislation of Russia. Historical and legal analysis]. M.: Os`-89. [in Russian].

11. Pushkareva, I. M. (2011). Trudovy`e konflikty` i rabochee dvizhenie v Rossii na rubezhe XIX-XX vv. [Labor conflicts and the labor movement in Russia at the turn of the XIX-XX centuries.]. SPb. : Aletejya. [in Russian].

12. Goncharenko, V. D., Rogozhin, A. J. \& Svyatocz kij O.D. (2003) Istoriia derzhavy i prava Ukrainy: pidruchnyk [History of State and Law of Ukraine: textbook]: [u 2 t.]. K.: Konczern 
«Vidavnichij di`m «I`n Yure», T. 1. [in Ukrainian].

13. Borisenko, V.J. Zakhidnoukrainski zemli v druhii polovyni KhIKh st. [Western Ukrainian lands in the second half of the nineteenth century]. Retrieved from: http://borysenko.npu.edu.ua/index.php/teksts/33-lekcia-30. [in Ukrainian].

14. Kiselev, I. Ya. (2001) Trudovoe pravo Rossii: istoriko-pravovoe issledovanie [Labor law in Russia: a historical and legal study]. M.: NORMA. [in Russian].

15. Slyusar`, A.N. (1995). Pravovy`e problemy` stanovleniya zakonodatel`stva Ukrainy`o poryadke razresheniya kollektivny`kh trudovy`kh sporov (konfliktov) [Legal problems of formation of the legislation of Ukraine on the procedure for resolving collective labor disputes (conflicts)]: Dis...kand. yurid. nauk: 12.00.05. Kh. [in Russian].

16. Tretii Universal Ukrainskoi Tsentralnoi Rady. 7 lystopada 1917 r. TsDAVO Ukrainy, f. 1115, op. 1, spr. 4, ark [Third Universal of the Ukrainian Central Council. November 7, 1917 TsDAVO of Ukraine, f. 1115, op. 1, file no. 4, p.]. Retrieved from: http://constituanta.blogspot.com/ 2011/03/i-1917_07.html [in Ukrainian].

17. Konstytutsiia Ukrainskoi Narodnoi Respubliky (Statut pro derzhavnyi ustrii, prava i vilnosti UNR) Derzhavni utvorennia (1917-1920) [Constitution of the Ukrainian People's Republic (Statute on the state system, rights and freedoms of the Ukrainian People's Republic) State formations (1917-1920)]. Retrieved from: http://zakon0.rada.gov.ua/laws/show/n0002300-18. [in Ukrainian].

18. Hlamazda, P. (2013). Posylennia karalnoi spriamovanosti zakonodavstva Ukrainskoi Derzhavy doby Hetmanatu Pavla Skoropadskoho(kviten - hruden1918 r.) [Strengthening the punitive orientation of the legislation of the Ukrainian State during the Hetmanate of Pavlo Skoropadsky (April - December 1918)]. Istoryko-pravovyi chasopys - Historical and legal journal. (2), (29-34) [in Ukrainian].

19. Prokopenko, V. I. (1998) Trudove pravo Ukrainy: Pidruchnyk [Labor law of Ukraine: Textbook]. H.: Firma «Konsum». [in Ukrainian].

20. Maliarenko, V. T. \& Ovchynnikov, Ye. I. (1997). Reabilitatsiia represovanykh: Zakonodavstvo i sudova praktyka [Rehabilitation of the repressed: Legislation and case law]. Kyiv: Yurinkom. [in Ukrainian].

21. Krainik, R. Straikovyi rukh robitnykiv pivdnia Ukrainy v pershii polovyni 1930-kh rokiv [Strike movement of workers in southern Ukraine in the first half of the 1930s]. Retrieved from: http://journal.mandrivets.com/images/file/Kraynik_2010_3.pdf [in Ukrainian].

22. Zakon SSSR ot 15 iyulya 1970 goda № 2-VIII «Ob utverzhdenii Osnov zakonodatel`stva Soyuza SSR i soyuzny`kh respublik o trude» [Law of the USSR of July 15, 1970 № 2-VIII "On Approval of the Fundamentals of the Legislation of the USSR and the Union Republics on Labor"]. Vedomosti Verkhovnogo Soveta SSSR - Bulletin of the Supreme Soviet of the USSR. (29), (265). [in Russian].

23. Lushnikova M.V. (1991). Trudovy`e spory`v SSSR : ucheb. Posobie [Labor disputes in the USSR: textbook. allowance]. Yaroslavl' : YarGU. [in Russian].

24. O poryadke razresheniya kollektivny`kh trudovy`kh sporov (konfliktov): Zakon SSSR ot 09.10.1989 № 580-I [On the procedure for resolving collective labor disputes (conflicts): Law of the USSR of 09.10.1989 № 580-I]. Vedomosti S`ezda narodny`kh deputatov SSSR $i$ Verkhovnogo Soveta SSSR - Bulletin of the Congress of People's Deputies of the USSR and the Supreme Soviet of the USSR. (18), (342). [in Russian].

25. O poryadke razresheniya kollektivny`kh trudovy`kh sporov (konfliktov): Zakon SSSR ot 23.11.1995 № 175-FZ [On the procedure for resolving collective labor disputes (conflicts): Law of 
the USSR of 23.11.1995№ 175-FZ]. Vedomosti S`ezda narodny`kh deputatov SSSR $i$ Verkhovnogo Soveta SSSR - Bulletin of the Congress of People's Deputies of the USSR and the Supreme Soviet of the USSR. (23), (654). [in Russian].

26. Kodeks zakoniv pro pratsiu URSR: Zakon vid 10.12.1971 № 322-VIII [Code of Labor Laws of the USSR: Law of 10.12.1971 № 322-VIII]. Vidomosti Verkhovnoi Rady - Information of the Verkhovna Rada. (50), (375). [in Ukrainian]. 